ISSN 1112-9867

http://www.jfas.info

\title{
METAL CONCENTRATION AT SURFACE WATER USING MULTIVARIATE ANALYSIS AND HUMAN HEALTH RISK ASSESSMENT
}

\author{
F. Azaman ${ }^{1}$, H. Juahir ${ }^{1,3,}{ }^{*}$, K. Yunus ${ }^{2}$, A. Azid ${ }^{3}$, S. I. Khalit ${ }^{3}$, A. D. Mustafa ${ }^{1}$, M. A. Amran ${ }^{1}$, C. N. C. \\ Hasnam $^{1}$, M. Z. A. Z. Abidin ${ }^{1}$ and M. A. M. Yusri ${ }^{1}$
}
${ }^{1}$ East Coast Environmental Research Institute (ESERI), Universiti Sultan Zainal Abidin, Gong Badak Campus, 21300 Kuala Nerus, Terengganu, Malaysia
${ }^{2}$ Kulliyyah of Science, International Islamic University Malaysia, 25200 Kuantan, Pahang, Malaysia
${ }^{3}$ Faculty of Bioresources and Food Industry, Universiti Sultan Zainal Abidin, Tembila Campus, 22200 Besut, Terengganu, Malaysia

Published online: 08 August 2017

\begin{abstract}
This study defined the concentration of metals in Kerteh and Paka River water and their potential health risk towards human. 54 water samples were collected and analyzed using ICP-OES. Results revealed that most of the stations in Kerteh River gave the higher concentration of $\mathrm{Cd}, \mathrm{Cu}$, $\mathrm{Zn}, \mathrm{Co}, \mathrm{Ni}, \mathrm{As}, \mathrm{Cr}$ and $\mathrm{Pb}$ compared to Paka River. However $\mathrm{As}, \mathrm{Cr}$ and $\mathrm{Pb}$ have exceeded the permissible limit of Malaysia standard for all stations in both rivers. $\mathrm{Cd}, \mathrm{Cu}, \mathrm{Zn}, \mathrm{Co}$ and $\mathrm{Ni}$ were below than Malaysian standard permissible levels during the sampling period. The principal component analysis (PCA) revealed that both geogenic and anthropogenic sources were responsible to possible metals contamination in both rivers. Moreover, risk assessments for all metals were within the safe limits, except for As in the Kerteh River for both adult and child as well as to Paka River for both genders.
\end{abstract}

Keywords: metal; ICP-OES; principal component analysis; risk assessment.

Author Correspondence, e-mail: hafizanjuahir@gmail.com

doi: http://dx.doi.org/10.4314/jfas.v9i2s.16 


\section{INTRODUCTION}

Heavy metals are basically derived from a variety of natural and anthropogenic sources in terms of aquatic environments [1-5]. Metal presence in nature is not dangerous to the environment because their small quantities [6]. Pollutions of heavy metal in surface water from natural processes occur due to the mineral weathering, erosion of bed rocks, volcanic activities and atmospheric deposition [7-9]. However, metal becomes a dangerous and pollutant if present in large quantities and usually attributed to industrial activities [10] and also known as anthropogenic sources [11-12].

Nowadays, industrial area such as mining industries widely discharge untreated heavy metal effluent into river water through various ways. River in urban areas was highly polluted due to the effluent discharge from industries and untreated domestic and become a problem that related to the water quality. These phenomena cause the levels of metal in water increase and automatically give a potential effect to the consumers [13-18]. In addition, global rapid population growth expanded the industrial and agricultural production and cause larger quantities of hazardous chemicals especially heavy metal have been discharged into rivers worldwide [19-21] and resulting to the water pollution.

In 2014, East Coast of Malaysia have been heavily impacted by major discharges from industrial outflows and also municipal especially at the Paka River after flooding occurrence. It is due to the rapid development of industry such as chemical manufacturing, oil and gas and others. Villagers more prefer fish as their main source of protein, therefore, the potential risk of heavy metals in river water should not be overlooked. The contamination of river water gives impact to the growth of fish and also can cause bad impact towards human health [22-24].

Maximum level for mercury $(\mathrm{Hg})$, zinc $(\mathrm{Zn})$ and cadmium $(\mathrm{Cd})$ in water concentrations were $0.02 \mu \mathrm{g} / 1,30 \mu \mathrm{g} / 1$ and $1.2 \mu \mathrm{g} / 1$ respectively based on the Canadian Guidelines [25]. In addition, according to the WHO (2004), the permissible limit for $\mathrm{Ni}, \mathrm{Cu}$ and $\mathrm{Cd}$ concentrations were 70 $\mu \mathrm{g} / 1,2000 \mu \mathrm{g} / \mathrm{l}$ and $3 \mu \mathrm{g} / \mathrm{l}$ respectively. In [27] stated that the maximum limit for As, $\mathrm{Cd}, \mathrm{Cr}, \mathrm{Cu}$ and $\mathrm{Pb}$ were $50 \mu \mathrm{g} / \mathrm{l}, 10 \mu \mathrm{g} / \mathrm{l}, 50 \mu \mathrm{g} / \mathrm{l}, 20 \mu \mathrm{g} / \mathrm{l}$ and $50 \mu \mathrm{g} / \mathrm{l}$ respectively under classification of Malaysian Water Quality Standard for river class IIA/IIB.

Mercury $(\mathrm{Hg})$ is a non-essential element. Toxicity of $\mathrm{Hg}$ could be harmful for fish and its organ [28-29]. In human, Hg may damage the fetal development due to their toxicity and also considered as a carcinogen [30]. In [31] studied that neuronal loss in the cerebellum granule layer 
and damage of discrete visual cortex area occurs in adult brain due to the $\mathrm{Hg}$ poisoning. However, chromium $(\mathrm{Cr})$ is an essential trace element in some animals and humans. $\mathrm{Cr}$ may reduce body fat and also improve lean body mass. But, it could have an undesirable fatal effect in excess amount. Lack of $\mathrm{Cr}$ may affected the growth and disturbances in glucose, lipid and protein metabolism [32]. Based on the above consideration, the present study aimed to identify the concentration of metal such as $\mathrm{Zn}, \mathrm{Ni}, \mathrm{Cu}, \mathrm{Pb}, \mathrm{Co}, \mathrm{Cr}$, As and $\mathrm{Cd}$ in river water. Analyses metal concentrations were performed using ICP-OES. Besides, multivariate statistical analysis was applied to identify the source apportionment of contaminated water in Paka River and Kerteh River. Finally, the potential health risk assessment associated with metal exposure was determined for the population living near the Paka River and Kerteh River.

\section{METHODOLOGY}

\subsection{Sampling Area}

The study area, Paka River and Kerteh River are located at the southern part of Terengganu. Paka River is originated from Dungun Watershed in Terengganu and it is about $100 \mathrm{~km}$ from south of Kuala Terengganu. Kuala Paka, Pantai Paka and Bandar Paka are places that located along the Paka River. Moreover, Kerteh River is located in the district of Kemaman also Southern Terengganu, Malaysia, about 2,536 $\mathrm{km}^{2}$ area with a population of 174,876 and also geographical location is $4^{\circ} 31^{\prime} 38^{\prime \prime} \mathrm{N}$ and $103^{\circ} 28^{\prime} 9^{\prime \prime}$ E. This river is flow from downstream of Kerteh to Batu Putih and Rangon River. Tanjung Kerteh, Pantai Kerteh, Kerteh Petronas Plant and Bandar Baru Kerteh are places that located along the Kerteh River. In total, there were eighteen sampling points along the Paka River and Kerteh River. The sampling points are at S1(P), S2(P), S3(P), S4(P), S5(P), S6(P), S7(P), S8(P), S9(P), S1(K), S2(K), S3(K), S4(K), S5(K), S6(K), S7(K), $\mathrm{S} 8(\mathrm{~K})$ and $\mathrm{S} 9(\mathrm{~K})$. Fig. 1 shows the selected sampling points along the Paka River and Kerteh River. 


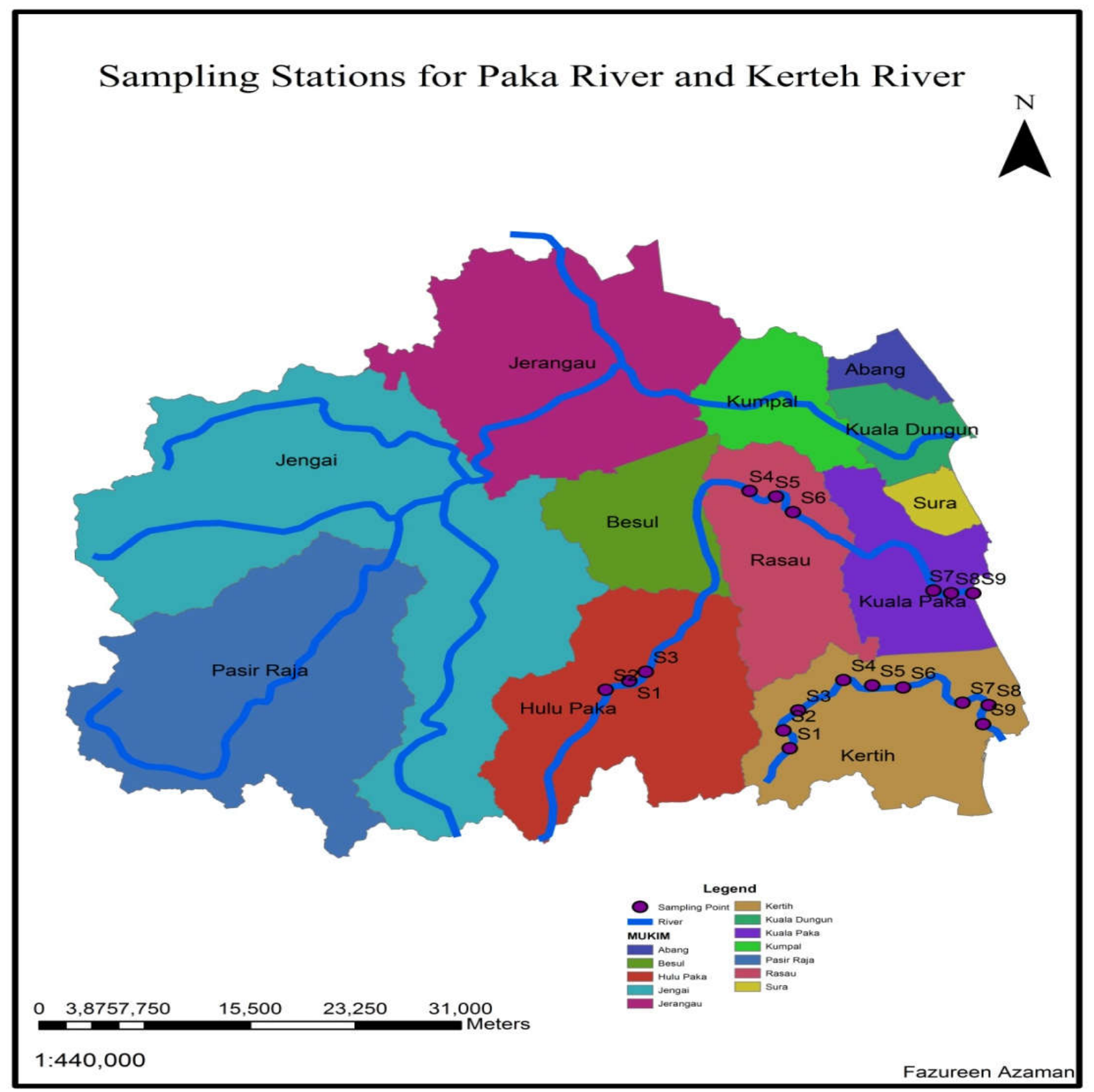

Fig.1. Sampling points along the Paka River and Kerteh River

\subsection{Sample Collection}

A total of fifty four of water samples were collected at nine stations in Paka River and nine stations at Kerteh River. Water samples were collected at depth of $<2$ meters using a water sampler and stored in 0.5 liter of polyethylene bottles. Water sample was taken in triplicate at each station and acidified with a few drops of high purity nitric acid to obtain value of $\mathrm{pH}$ around 2 in order to prevent the biological growth and precipitation of metals [33-34]. Thereafter, samples were preserved in iceboxes at $-18^{\circ} \mathrm{Celsius}$ before begin for water analysis [35]. 


\subsection{Chemical Analysis by ICP-OES}

All acidified water samples were analyzed for Cadmium (Cd), Nickel (Ni), Lead (Pb), Zinc (Zn), Chromium (Cr), Copper ( $\mathrm{Cu}$ ), Cobalt (Co) and Arsenic (As) using an Inductively Coupled Plasma-Optical Emission Spectrometry. Innovative ICP-OES technology was driven by the Thermo Scientific ${ }^{\mathrm{TM}}$ Qtegra $^{\mathrm{TM}}$ Intelligent Scientific Data Solution ${ }^{\mathrm{TM}}$ (ISDS) software platform.

\subsection{Quality Assurance and Quality Control}

The quality of the result obtained by the accuracy of the method used including the standard operating procedures, chemical blank analysis, replicate analysis and standard certified reference materials analysis. For water samples, the certified reference materials of the National Institute of Standards and Technology (river water: NIST SRM 1643b-trace metal in water) was used. The recovery studies are performed to detect metal losses or contamination of the sample during preparation and also to identify any interference during measurement [36]. The percentage of recovery were accepted between $95 \%$ to $110 \%$, which is observed from the relationship between certified values and measured values as shown in Table 1. Besides, a multielement calibration standards act as calibration blank also was analyzed to confirm the calibration performance of the ICP-OES. All analyses were carried out in triplicate.

Table 1. Recovery of metal using certified reference materials of water sample

\begin{tabular}{cccc}
\hline Metal & \multicolumn{3}{c}{ River Water (NIST SRM 1643b) } \\
& Certified Value $(\boldsymbol{\mu g} / \mathbf{l})$ & Measured Value $(\boldsymbol{\mu g} / \mathbf{l})$ & Recovery $(\%)$ \\
\hline $\mathrm{Cd}$ & $12.2 \pm 1.0$ & $12.0 \pm 0.1$ & 98.36 \\
$\mathrm{Cr}$ & $17.6 \pm 0.1$ & $18.8 \pm 0.4$ & 106.82 \\
$\mathrm{Zn}$ & $73.9 \pm 0.9$ & $70.0 \pm 0.8$ & 94.72 \\
$\mathrm{Cu}$ & $22.3 \pm 2.8$ & $21.6 \pm 0.4$ & 96.86 \\
$\mathrm{Ni}$ & $47.2 \pm 0.1$ & $49.0 \pm 2.8$ & 103.81 \\
$\mathrm{~Pb}$ & $35.3 \pm 0.9$ & $34.4 \pm 0.5$ & 81.90 \\
$\mathrm{As}$ & $42.0 \pm 0.2$ & $43.0 \pm 3.0$ & 102.38 \\
$\mathrm{Co}$ & $24.0 \pm 0.4$ & $26.0 \pm 1.0$ & 108.33 \\
\hline
\end{tabular}

\subsection{Data Analysis}

In this research, principal component analysis (PCA) was performed to the data set to exclude insignificant data. This analysis is based on eigenvalue criteria where value $>1$ is considered as significant and a new group of variables built based on the resemblance of the entire data set [37]. 
PCA technique was applied to extract the principal factors corresponding to the different sources of variation in the data of physical and chemical from Kerteh River and Paka River. For this study, factor loading $>0.75$ for both positive and negative was considered [38] as well. Before applying data analysis using PCA, Kaiser-Meyer Olkin (KMO) and Barlett's test should be performed first. KMO test results must be greater than 0.5 and the Barlett's test must be significant (significant level < 0.05) [39-40]. Data were statistically calculated and analyzed using the XLSTAT software.

\subsection{Health Risk Assessment}

In order to estimate the non-cancer health risk, hazard quotient (HQ) was calculated. Thus, HQ can be calculated by the equation [41]:

$\mathrm{H}=\frac{\mathrm{CDI}}{\mathrm{RfD}}$

where $\mathrm{CDI}=$ chronic daily intake, $\mathrm{RfD}=$ reference dose for an individual metal $\left(3 \times 10^{-4}, 3 \times 10^{-4}\right.$, $1.5,3.6 \times 10^{-2}, 4 \times 10^{-2}, 2 \times 10^{-2}, 3 \times 10^{-1}$ and $1 \times 10^{-3} \mathrm{mg} / \mathrm{kg} /$ day for $\mathrm{Hg}, \mathrm{As}, \mathrm{Cr}, \mathrm{Pb}, \mathrm{Cu}, \mathrm{Ni}, \mathrm{Zn}$ and $\mathrm{Cd}$ respectively based on [42].

The exposed population considered safe when HQ less than 1 [43-44]. Several ways for metal enters into the human body, such as food chains, inhalation and dermal absorption, but become negligible if compared with oral intake all others $[8,45]$. Chronic daily intake (CDI) through ingestion of water can be calculated by following equation [46]:

$\mathrm{CDI}=\frac{\mathrm{C} \times \mathrm{DI}}{\mathrm{BW}}$

where $\mathrm{C}=$ concentration of heavy metal in water $(\mu \mathrm{g} / \mathrm{L}), \mathrm{DI}=$ rate of daily water intake (adult: $2 \mathrm{~L} /$ day and child: $1 \mathrm{~L} /$ day) and $\mathrm{BW}=$ body weight (adult: $62.65 \mathrm{~kg}$ and child: $31.20 \mathrm{~kg}$ )

\section{RESULTS AND DISCUSSION}

\subsection{Metal Concentration in Surface River Water}

The result of metal concentration in surface water of the Paka and Kerteh River are shown in the Table 2. Metal presence in nature is not dangerous to the environment because their small quantities [6]. Pollutions of heavy metal in surface water from natural processes occur due to the mineral weathering, erosion of bed rocks, volcanic activities and atmospheric deposition [8, 43]. However, metal becomes a dangerous and pollutant if present in large quantities [10].

In Paka River, the maximum value of As in the S7 (54.900 $\mu \mathrm{g} / 1)$, S8 (62.533 $\mu \mathrm{g} / \mathrm{l})$ and S9 (56.200 $\mu \mathrm{g} / \mathrm{l})$ was higher than $[27,41,47]$ guidelines. While, the maximum concentrations of As in the S2 
and S4 at the Kerteh River were found to exceed [27, 41, 47] guidelines (Table 2). Elevated level of As in the river have resulted from an incline number of land use activities such as urbanization, industrial and mining activities [48]. The higher concentrations of As in the selected regions may be also because of chemical fertilizers used in the surrounding agriculture fields [49]. Thus, these wastes will runoff into the river especially during wet season and resulting to the high measured arsenic. Moreover, additional environmental impact also known as health risk assessments are necessary for metal levels above the maximum allowable limits. In Malaysia, the maximum permitted As concentration was $50 \mu \mathrm{g} / 1$ according to [27].

The highest level of Cd in the Paka River was found at the S7 $(0.334 \mu \mathrm{g} / \mathrm{l})$ and the lowest level of $\mathrm{Cd}$ was found at the $\mathrm{S} 1(0.003 \mu \mathrm{g} / \mathrm{l})$ near to the upstream. While, the highest concentrations of $\mathrm{Cd}$ in the Kerteh River were found at the S6 $(0.322 \mu \mathrm{g} / 1)$ and the lowest level of $\mathrm{Cd}$ was found at the $\mathrm{S} 1(0.010 \mu \mathrm{g} / \mathrm{l})$ near to the upstream as shown in Table 2 . This is due to the many industries area may contributes to the metal pollution by discharge their waste into river. In addition, $\mathrm{Cd}$ is generally produced by industrial processes or known as sludge-derived fertilizers. The major sources of cadmium pollution are smelting and refining of zinc, lead and copper ores, manufacture of cadmium alloys, pigments and plastic stabilizers, production of nickel-cadmium batteries and also welding [50]. Thus, discharges of wastewater from $\mathrm{Cd}$ factories contribute to the pollution of cadmium [51]. The use of $\mathrm{Cd}$ in plating, stabilizers, pigments and batteries ensure the continuing demand for $\mathrm{Cd}$ in the market and become one of the possible sources for environmental pollution [52]. However, all sampling station in the both river does not show that the concentration of $\mathrm{Cd}$ above than the maximum permitted by Malaysia guideline which is 10 $\mu \mathrm{g} / 1[27]$.

The maximum value of $\mathrm{Cr}$ in the $\mathrm{S} 6(101.000 \mu \mathrm{g} / \mathrm{l}), \mathrm{S} 7(197.000 \mu \mathrm{g} / \mathrm{l}), \mathrm{S} 8(248.667 \mu \mathrm{g} / \mathrm{l})$ and $\mathrm{S} 9$ $(255.333 \mu \mathrm{g} / \mathrm{l})$ at the Paka River was above than the maximum permitted by Malaysia guidelines. While, the maximum concentrations of $\mathrm{Cr}$ in the $\mathrm{S} 2(106.267 \mu \mathrm{g} / \mathrm{l}), \mathrm{S} 3(118.667 \mu \mathrm{g} / \mathrm{l}), \mathrm{S} 4$ (156.667 $\mu \mathrm{g} / \mathrm{l}), \mathrm{S} 5(109.800 \mu \mathrm{g} / \mathrm{l}), \mathrm{S} 6(112.467 \mu \mathrm{g} / \mathrm{l}), \mathrm{S} 7(201.633 \mu \mathrm{g} / \mathrm{l}), \mathrm{S} 8(250.633 \mu \mathrm{g} / \mathrm{l})$ and $\mathrm{S} 9$ $(291.800 \mu \mathrm{g} / \mathrm{l})$ at the Kerteh River were found to exceed Malaysia guidelines (Table 2). Environmental pollution with various forms of $\mathrm{Cr}$ results from its numerous uses in the chemical industry, wood preservations, chrome plating, dyes production, leather tanning, alloys manufacturing and in many other products and applications [53-57]. $\mathrm{Cr}$ in trivalent and hexavalent forms is normally used in chemical industries [57]. Thus, this is due to the many 
industries in the Kerteh may discharge their waste into the river and caused the level of $\mathrm{Cr}$ in the river increased. Moreover, additional environmental impact also known as health risk assessments are necessary for metal levels above the maximum allowable limits. The maximum permitted $\mathrm{Cr}$ concentration based on Malaysia guidelines was $50 \mu \mathrm{g} / 1$ [27].

Based on the result obtained in the Table 2, the highest level of $\mathrm{Cu}$ in the Paka River was found at the S8 $(18.567 \mu \mathrm{g} / \mathrm{l})$ near to the downstream and the lowest level of $\mathrm{Cu}$ was found at the S2 $(0.134 \mu \mathrm{g} / \mathrm{l})$ near to the upstream. While, the highest concentrations of $\mathrm{Cu}$ in the Kerteh river were found at the S8 $(11.947 \mu \mathrm{g} / \mathrm{l})$ near to the downstream and the lowest level of $\mathrm{Cu}$ was found at the $\mathrm{S} 1(0.030 \mu \mathrm{g} / \mathrm{l})$ near to the upstream. However, all sampling station in the both river does not show that the concentration of $\mathrm{Cu}$ above than the maximum permitted by Malaysia guideline which is $20 \mu \mathrm{g} / 1$ [27]. Basically, $\mathrm{Cu}$ is an essential metabolic component in low concentrations and caused illness in high concentration as well as accumulates in tissues and prolonged exposure also can lead to illness. Heavy industry and mining activities can result in higher concentrations than those that would be found naturally [68]. In addition, the major release of $\mathrm{Cu}$ into the environment was municipal waste, agriculture and also publicly-owned treatment work (POTWs) [69]. Waste from these activities runoff with rainwater and resulting to the high measured copper concentration in river. $\mathrm{Cu}$ contaminations could result from local agriculture activities.

Highest $\mathrm{Pb}$ concentration was found in S8 $(73.200 \mu \mathrm{g} / \mathrm{l})$, while $\mathrm{S} 1(0.280 \mu \mathrm{g} / \mathrm{l})$ has the lowest $\mathrm{Pb}$ concentration in the Kerteh River. Paka River showed that the highest $\mathrm{Pb}$ concentration was found in S7 $(69.733 \mu \mathrm{g} / \mathrm{l})$, while the lowest $\mathrm{Pb}$ concentration was found in S2 $(0.044 \mu \mathrm{g} / \mathrm{l})$ as shown in the Table 2. Naturally, lead occurs from the parent rocks decomposition. However, lead may accumulate from anthropogenic sources including traffic exhaust, lead-zinc smelters, dumps and other sites receiving industrial and household lead such as paints and batteries [57]. In addition, spillages or leakages of leaded petrol from the ship or boat also become one of the possible anthropogenic sources of $\mathrm{Pb}[26,58]$. Based on the result obtained, most of the sampling stations were above the Malaysia standard which is $20 \mu \mathrm{g} / 1$ [27] and thus they could be classified as unclean Pb areas. Station S6, S7, S8 and S9 for Paka River and station S3, S4, S5, S6, S7, S8 and S9 for Kerteh River are noted to have high values of exceed the maximum permitted limit by Malaysia guideline.

The highest Zn concentration in the Paka River was found at the S9 $(153.667 \mu \mathrm{g} / \mathrm{l})$ near to the downstream and the lowest $\mathrm{Zn}$ concentration was found at the $\mathrm{S} 1(1.937 \mu \mathrm{g} / \mathrm{l})$ near to the 
upstream. While, the highest $\mathrm{Zn}$ concentrations in the Kerteh River were found at the S8 $(132.500 \mu \mathrm{g} / \mathrm{l})$ near to the downstream and the lowest $\mathrm{Zn}$ concentration was found at the S1 $(2.320 \mu \mathrm{g} / \mathrm{l})$ near to the upstream (Table 2). Zinc occurs naturally in air, water and soil but concentration of zinc is rising unnaturally due to addition of zinc through human activities. The pollution related to the zinc usually comes from either zinc electroplating or zinc mining. However, the pollution of zinc in this area must be derived from zinc electroplating factories due there are no zinc mines in this area. Thus, this factor represents zinc pollution from industrial discharge. For example, tire-tread material has containing about 1wt\% of Zn [59]. Zn-based fungicides or burning of agriculture waste also can be an additional of zinc source [60-61]. In addition, this probably occurs due to the transport of chemical or agriculture waste leachate with the runoff of rainwater [62]. However, all sampling station in the both river does not show that the concentration of $\mathrm{Zn}$ above than the maximum permitted by Malaysia guideline which is 400 $\mu \mathrm{g} / 1[27]$.

The highest level of Co in the Paka River was found at the S9 $(10.630 \mu \mathrm{g} / \mathrm{l})$ near to the downstream and the lowest level of Co was found at the S1 $(0.010 \mu \mathrm{g} / \mathrm{l})$ near to the upstream. While, the highest levels of Co in the Kerteh River were found at the S8 $(8.407 \mu \mathrm{g} / \mathrm{l})$ and the lowest level of Co was found at the S1 $(0.003 \mu \mathrm{g} / \mathrm{l})$ near to the upstream (Table 2). Typically, cobalt is naturally found in most soil, rocks, animals, plants and water in small amounts. In human activities, cobalt metal is usually used by mixing with other metals to form alloys which are more resistant and harder. These alloys are used in industrial and military applications such as grinding and cutting tools, magnets and aircraft engines. They are also used in artificial knee and hip joints. In terms of compound, cobalt are used as catalysts, paint driers and also as colorants in ceramics, glass and paints and also used as trace element additives in medicine and agriculture [63]. These activities contribute to the metal pollution like cobalt through discharging their waste into river. The concentration of cobalt might become higher due to the industry waste runoff with rainwater. In addition, all sampling station in the both river does not show that the concentration of Co above than the maximum allowable limit by [47] which is $500 \mu \mathrm{g} / \mathrm{l}$.

The highest Ni concentration was found in S9 $(125.640 \mu \mathrm{g} / 1)$, while $\mathrm{S} 1(0.030 \mu \mathrm{g} / \mathrm{l})$ has the lowest Ni concentration in the Kerteh River. Paka River showed that the highest Ni concentration was found in S8 $(142.373 \mu \mathrm{g} / \mathrm{l})$, while the lowest Ni concentration was found in S1 $(0.046 \mu \mathrm{g} / \mathrm{l})$ (Table 2). Based on the result obtained, all sampling station in the both river does not show that 
the concentration of $\mathrm{Ni}$ exceed than the maximum permitted limit by Malaysia standard which is $900 \mu \mathrm{g} / 1$ [27]. Many years, nickel is used mainly in the production of stainless steel about $42 \%$, $36 \%$ for alloy production such as non-ferrous alloys and super alloys. Other uses of nickel were in electroplating (18\%), in nickel-cadmium batteries, in construction like welding products, in coinage and in certain electronic products. $8 \%$ of nickel is used for appliances of household [64]. Besides, in some food supplements, nickel is also incorporated which can contain several micrograms of nickel [65]. Waste from these activities directly or partly discharge into the river and automatically contributes to the nickel pollution.

Table 2. Metal concentration of surface water from Paka and Kerteh River

\begin{tabular}{|c|c|c|c|c|c|c|c|c|c|}
\hline Location & ID & Co & $\mathbf{C u}$ & $\mathbf{N i}$ & $\mathbf{Z n}$ & As & $\mathrm{Cr}$ & Cd & $\mathbf{P b}$ \\
\hline Paka & $\mathrm{S} 1$ & 0.010 & 0.185 & 0.046 & 1.937 & 3.777 & 0.225 & 0.003 & 0.085 \\
\hline \multirow[t]{8}{*}{ River } & $\mathrm{S} 2$ & 0.017 & 0.134 & 0.060 & 3.437 & 4.467 & 0.291 & 0.010 & 0.043 \\
\hline & $\mathrm{S} 3$ & 0.036 & 0.280 & 0.053 & 4.070 & 4.443 & 0.442 & 0.017 & 0.077 \\
\hline & $\mathrm{S} 4$ & 0.037 & 0.269 & 0.066 & 1.633 & 3.867 & 0.356 & 0.050 & 0.058 \\
\hline & S5 & 0.080 & 0.546 & 0.139 & 3.317 & 5.067 & 0.554 & 0.003 & 0.173 \\
\hline & S6 & 4.760 & 10.433 & 55.133 & 100.933 & 33.400 & 101.000 & 0.204 & 60.100 \\
\hline & S7 & 7.593 & 12.233 & 104.867 & 121.667 & 54.900 & 197.000 & 0.334 & 69.733 \\
\hline & S8 & 10.353 & 18.567 & 142.373 & 121.500 & 62.533 & 248.667 & 0.237 & 55.007 \\
\hline & S9 & 10.630 & 13.667 & 125.267 & 153.667 & 56.200 & 255.333 & 0.287 & 63.647 \\
\hline Kerteh & $\mathrm{S} 1$ & 0.003 & 0.030 & 0.030 & 2.320 & 0.983 & 0.000 & 0.010 & 0.280 \\
\hline \multirow[t]{8}{*}{ River } & $\mathrm{S} 2$ & 2.963 & 6.177 & 40.200 & 14.767 & 19.533 & 106.267 & 0.212 & 12.367 \\
\hline & $\mathrm{S} 3$ & 4.857 & 7.373 & 50.367 & 83.933 & 28.450 & 118.667 & 0.157 & 43.167 \\
\hline & $\mathrm{S} 4$ & 4.650 & 7.817 & 53.533 & 26.900 & 44.833 & 156.667 & 0.308 & 28.367 \\
\hline & S5 & 3.910 & 9.597 & 62.033 & 70.433 & 62.133 & 109.800 & 0.157 & 42.833 \\
\hline & S6 & 4.170 & 10.800 & 63.367 & 43.233 & 56.067 & 112.467 & 0.322 & 22.267 \\
\hline & S7 & 5.573 & 10.460 & 84.133 & 115.000 & 41.300 & 201.633 & 0.218 & 46.300 \\
\hline & S8 & 8.407 & 11.947 & 102.000 & 132.500 & 74.733 & 250.633 & 0.127 & 73.200 \\
\hline & S9 & 5.423 & 5.877 & 125.640 & 34.367 & 30.267 & 291.800 & 0.043 & 21.133 \\
\hline
\end{tabular}

\subsection{Sources of Water Pollution}

PCA technique was applied in order to determine the source of pollution in Kerteh River and Paka River. Correlation analysis, Kaiser-Meyer-Olkin (KMO) and Bartlett's sphericity tests were 
performed to examine the validity of PCA. In the Kerteh River, KMO and Bartlett's results were 0.722 (greater than 0.5 ) and significant $(0.0001, \mathrm{p}<0.05)$ respectively indicating that PCA would be effective in reducing dimensionality of the data set $[38,40]$. The correlation analysis of 16 physico-chemical parameter of Kerteh River water is listed in Table 3.

In this study, PCA of the normalized dataset extracted by varimax rotation of PCs with eigenvalues $>1$ has been selected. There were two varifactors (VFs) that explained about surface water having $79.83 \%$ of the total variance in the data set (Table 4). The first PC (VF1) accounting for $53.04 \%$ of the total variance was correlated (strong loading $>0.75)$ with $\mathrm{Cr}$, Co and $\mathrm{Ni}(\mathrm{r}=$ 0.891-0.930) and moderate loading on $\mathrm{As}, \mathrm{Cu}, \mathrm{Pb}$ and $\mathrm{Zn}(\mathrm{r}=0.556-0.716)$. Naturally, $\mathrm{Cr}, \mathrm{Co}, \mathrm{Ni}$, $\mathrm{As}, \mathrm{Cu}, \mathrm{Pb}$ and $\mathrm{Zn}$ occur in the earth's crust and natural discharges into water and air such as rock or soil weathering and erosion in small amount. However, the presence of these metals to the environment normally caused by anthropogenic activities like chemical industry activities, agriculture activities and municipal waste. Manufacturing alloy is the major contribution from industry area $[54,60,63]$. Besides, these metals were used as fertilizer in agriculture activities $[49,63]$.

The second PC (VF2) accounting for $26.79 \%$ of total variance was correlated with strong loading on $\mathrm{Cd}$ with $\mathrm{r}=0.792$ and moderate loading on $\mathrm{As}, \mathrm{Cu}$ and $\mathrm{Pb}(\mathrm{r}=0.542-0.695)$. At the beginning of the 20th century, cadmium commercially used in the electroplating industry and followed by production of nickel-cadmium batteries [66]. Other metals like $\mathrm{As}, \mathrm{Cu}$ and $\mathrm{Pb}$ also used in manufacturing alloy and non-alloy [49]. All these activities contribute to the water pollution by discharge their waste directly (treated or untreated waste) into the river. In fact, study area are famous with busy town thriving on oil and gas activity and also other industries, agriculture activities included surrounding crowded with residential area especially in the peak area.

For the dataset of Paka River, KMO and Bartlett's results were 0.817 (greater than 0.5) and significant $(0.0001, \mathrm{p}<0.05)$ respectively indicating that PCA would be effective in reducing dimensionality of the data set $[38,40]$. The correlation analysis also was applied to confirm all the variables are correlated as shown in Table 3. In the case of Paka River, only one PC was defined after rotation and having about $94.11 \%$ of the total variance (Table 4). These PC showed correlated with positive and strong loading on $\mathrm{As}, \mathrm{Cd}, \mathrm{Cr}, \mathrm{Cu}, \mathrm{Pb}, \mathrm{Zn}, \mathrm{Co}$ and $\mathrm{Ni}$ with $\mathrm{r}=$ 0.958-0.985. All these metals indicate that non-point sources and point source of pollution probably occurs. The non-point sources normally came from agricultural waste and point sources 
from industrial waste. Basically, these metals could be classified as metal pollution. The existence of trace metal in this region indicates the effect of oil pollution from petroleum mining and chemical industries and might be directly discharge into the river and resulting to the river pollution $[38,67]$. However, these metal also used as pesticide and fertilizer in the agriculture activity. Municipal solid waste also gave the contribution to the water pollution and usually come from residential area, school and others $[49,73]$. Improper sewage treatment plant or also known as wastewater treatment plant (treat household waste, liquid waste from industry and other) also one of the sources of the water pollution [70].

Table 3. Correlation matrices of metal in water

\begin{tabular}{|c|c|c|c|c|c|c|c|c|}
\hline \multicolumn{9}{|c|}{ Kerteh River } \\
\hline & As & $\mathrm{Cd}$ & $\mathrm{Cr}$ & $\mathrm{Cu}$ & $\mathrm{Pb}$ & $\mathrm{Zn}$ & $\mathrm{Co}$ & $\mathrm{Ni}$ \\
\hline As & 1 & & & & & & & \\
\hline $\mathrm{Cd}$ & 0.367 & 1 & & & & & & \\
\hline $\mathrm{Cr}$ & 0.447 & 0.015 & 1 & & & & & \\
\hline $\mathrm{Cu}$ & 0.787 & 0.318 & 0.443 & 1 & & & & \\
\hline $\mathrm{Pb}$ & 0.734 & 0.156 & 0.514 & 0.746 & 1 & & & \\
\hline $\mathrm{Zn}$ & 0.626 & 0.037 & 0.453 & 0.741 & 0.898 & 1 & & \\
\hline Co & 0.678 & 0.088 & 0.797 & 0.765 & 0.799 & 0.747 & 1 & \\
\hline $\mathrm{Ni}$ & 0.518 & -0.055 & 0.927 & 0.585 & 0.537 & 0.527 & 0.807 & 1 \\
\hline \multicolumn{9}{|c|}{ Paka River } \\
\hline & As & $\mathrm{Cd}$ & $\mathrm{Cr}$ & $\mathrm{Cu}$ & $\mathrm{Pb}$ & $\mathrm{Zn}$ & $\mathrm{Co}$ & $\mathrm{Ni}$ \\
\hline As & 1 & & & & & & & \\
\hline $\mathrm{Cd}$ & 0.938 & 1 & & & & & & \\
\hline $\mathrm{Cr}$ & 0.962 & 0.896 & 1 & & & & & \\
\hline $\mathrm{Cu}$ & 0.944 & 0.936 & 0.913 & 1 & & & & \\
\hline $\mathrm{Pb}$ & 0.933 & 0.962 & 0.891 & 0.975 & 1 & & & \\
\hline $\mathrm{Zn}$ & 0.948 & 0.931 & 0.960 & 0.967 & 0.947 & 1 & & \\
\hline Co & 0.960 & 0.896 & 0.959 & 0.928 & 0.887 & 0.946 & 1 & \\
\hline $\mathrm{Ni}$ & 0.962 & 0.883 & 0.955 & 0.884 & 0.866 & 0.941 & 0.941 & 1 \\
\hline
\end{tabular}

Note: Values in bold are different from 0 with a significance level alpha $=0.05$ 
Table 4. Varimax rotated after component matrix for both rivers

\begin{tabular}{cccc}
\hline & \multicolumn{2}{c}{ Kerteh River } & Paka River \\
& Components & Components \\
& VF1 & VF2 & VF1 \\
\hline $\mathrm{As}$ & 0.556 & 0.695 & 0.985 \\
$\mathrm{Cd}$ & -0.201 & 0.792 & 0.959 \\
$\mathrm{Cr}$ & 0.891 & -0.058 & 0.971 \\
$\mathrm{Cu}$ & 0.629 & 0.660 & 0.973 \\
$\mathrm{~Pb}$ & 0.716 & 0.542 & 0.961 \\
$\mathrm{Zn}$ & 0.713 & 0.454 & 0.985 \\
$\mathrm{Co}$ & 0.905 & 0.303 & 0.969 \\
$\mathrm{Ni}$ & 0.930 & -0.021 & 0.958 \\
Eigenvalues & 5.072 & 1.314 & 7.529 \\
Variance explained (\%) & 53.04 & 26.79 & 94.11 \\
Cumulative variance $(\%)$ & 53.04 & 79.83 & 94.11
\end{tabular}

Note: Bold and italic values indicate strong and moderate loadings respectively

\subsection{Health Risk Assessment for Water Consumption}

Metal concentrations in surface water were used to assess human exposure through oral intake. In this study, two population groups were considered which are adults and child. The chronic daily intake (CDI) and hazard quotient (HQ) through ingestion of water is summarized in Table 5. HQ by ingestion for adult and child, resulting that all elements $(\mathrm{Co}, \mathrm{Cu}, \mathrm{Ni}, \mathrm{Zn}, \mathrm{Pb}$, $\mathrm{Cr}, \mathrm{Cd}$ ) were smaller than 1 except for As for Kerteh River and Paka River. The highest value of As indicated to the Kerteh River were above 3 (3.686 and 4.058 for adult and child respectively), followed by Paka River. Besides, the aggregate HQ of every metals for adult and child in the Kerteh River were found in the decreasing order of $\mathrm{As}>\mathrm{Co}>\mathrm{Ni}>\mathrm{Pb}>\mathrm{Cu}>$ $\mathrm{Zn}>\mathrm{Cd}>\mathrm{Cr}$. HQ for adult and child in the Paka River were found in the decreasing order of $\mathrm{As}>\mathrm{Co}>\mathrm{Ni}>\mathrm{Pb}>\mathrm{Zn}>\mathrm{Cu}>\mathrm{Cd}>\mathrm{Cr}$.

This value shows the level of As was very high that may cause adverse health effects and potential non-carcinogenic concern. The result also indicated that As posed serious health concerns to the local residents via oral intake for all the seasons, while other metals had no or little health threat. Additionally, As exclusively with the HQ for adult and child above unity was the largest contributor to non-carcinogenic concern. Though, it can be inferred that As was the most contributors in all the seasons and the oral intake was the primary pathway of exposure. The risk assessment indicated that As was the most important pollutant in the both 
Paka and Kerteh River. Inorganic arsenic is acutely toxic and intake of large quantities leads to the symptoms of gastrointestinal, severe disturbances of the cardiovascular and central nervous systems and eventually death. However, for survivors, bone marrow depression, hemolysis, hepatomegaly, melanosis, polyneuropathy and encephalopathy may be observed. Ingestion of inorganic arsenic may cause peripheral vascular disease, which in its extreme form leads to gangrenous changes and also known as black foot disease. This disease only reported in Taiwan. The exposure of arsenic via drinking water towards population show excess risk of mortality from lung, bladder and kidney cancer. In [71] also stated that population exposed to arsenic via drinking water is causally related to cancer in the lungs, kidney, bladder and skin. There is also an increased risk of other skin lesions such as hyperkeratosis and pigmentation changes. The risk increasing with increasing exposure. However, toxicity of As depends on the speciation [72] and trivalent As (III) has the greatest toxicity. According to [54], mono and dimethyl arsenics have low toxicity.

Table 5. Reference dose and hazard quotient for each element of the Paka and Kerteh River

\begin{tabular}{llccccc}
\hline & & & \multicolumn{2}{c}{ CDI } & \multicolumn{2}{c}{ HQ } \\
& Elements & *RfD & Adult & Child & Adult & Child \\
& & $(\mathbf{m g} / \mathbf{k g} /$ day $)$ & & & & \\
\hline Kerteh River & $\mathrm{As}$ & 0.0003 & 1.1059 & 1.2175 & $\mathbf{3 . 6 8 6 2}$ & $\mathbf{4 . 0 5 8 2}$ \\
& $\mathrm{Cd}$ & 0.0010 & 0.0048 & 0.0053 & 0.0048 & 0.0053 \\
& $\mathrm{Cr}$ & 1.5000 & 4.1603 & 4.5801 & 0.0028 & 0.0031 \\
& $\mathrm{Cu}$ & 0.0400 & 0.2163 & 0.2381 & 0.0054 & 0.0060 \\
& $\mathrm{~Pb}$ & 0.0360 & 0.8948 & 0.9851 & 0.0249 & 0.0274 \\
& $\mathrm{Zn}$ & 0.3000 & 1.6156 & 1.7786 & 0.0054 & 0.0059 \\
& $\mathrm{Co}$ & 0.0003 & 0.1233 & 0.1358 & 0.4111 & 0.4526 \\
& $\mathrm{Ni}$ & 0.0200 & 1.7941 & 1.9752 & 0.0897 & 0.0988 \\
& $\mathrm{As}$ & 0.0003 & 0.7057 & 0.7769 & $\mathbf{2 . 3 5 2 4}$ & $\mathbf{2 . 5 8 9 8}$ \\
& $\mathrm{Cd}$ & 0.0010 & 0.0035 & 0.0039 & 0.0035 & 0.0039 \\
& $\mathrm{Cr}$ & 1.5000 & 2.4811 & 2.7315 & 0.0017 & 0.0018 \\
& $\mathrm{Cu}$ & 0.0400 & 0.1738 & 0.1913 & 0.0043 & 0.0048 \\
$\mathrm{~Pb}$ & 0.0360 & 0.7683 & 0.8458 & 0.0213 & 0.0235 \\
$\mathrm{Zn}$ & 0.3000 & 1.5807 & 1.7403 & 0.0053 & 0.0058 \\
$\mathrm{Co}$ & 0.0003 & 0.1034 & 0.1139 & 0.3448 & 0.3796 \\
$\mathrm{Ni}$ & 0.0200 & 1.3210 & 1.4543 & 0.0660 & 0.0727 \\
\hline & & & & & &
\end{tabular}




\section{CONCLUSION}

The amount of metals at surface river water though the levels were below Malaysia standard maximum permissible levels for $\mathrm{Cr}, \mathrm{Pb}, \mathrm{Cd}, \mathrm{Cu}, \mathrm{Zn}$, $\mathrm{Co}$ and $\mathrm{Ni}$ for all sampling point in the both river. In few cases, the levels of As exceeded the Malaysia standard maximum permissible limit. In overall, most of the sampling point in the Kerteh River gave the higher concentration on metal contents $(\mathrm{Cd}, \mathrm{Cu}, \mathrm{Zn}, \mathrm{Co}, \mathrm{Ni}, \mathrm{As}, \mathrm{Cr}, \mathrm{Pb})$ compared to the Paka River. In addition, PCA is successfully applied into experimental data by extracting i) two PCs for Kerteh River and ii) only one PC for Paka River out of the 8 original variables, which implies a great dimensionality reduction in order to classify water pollution based on their similar characteristics. Moreover, risk assessments for metals were within safe limits, except for As (adult and child) in the both rivers. Therefore, it suggested that the water from contaminated sites should not be used for drinking without proper treatment.

\section{ACKNOWLEDGEMENTS}

This work was supported by East Coast Environmental Research Institute (ESERI), Universiti Sultan Zainal Abidin (UniSZA), Gong Badak Campus, Kuala Terengganu and Kulliyah of Science, International Islamic University Malaysia, Kuantan, Pahang, Malaysia.

\section{REFERENCES}

[1] Macklin M G, Brewer P A, Hudson-Edwards K A, Bird G, Coulthard T J, Dennis I A, Lechler P J, Miller J R, Turner J N. A geomorphological approach to the management of rivers contaminated by metal mining. Geomorphology, 2006, 79(3):423-447

[2] Demirak A, Yilmaz F, Tuna A L, Ozdemir N. Heavy metals in water, sediment and tissues of Leuciscus cephalus from a stream in southwestern Turkey. Chemosphere, 2006, 63(9):1451-1458

[3] Li S, Xu Z, Cheng X, Zhang Q. Dissolved trace elements and heavy metals in the Danjiangkou Reservoir, China. Environmental Geology, 2008, 55(5):977-983

[4] Li S, Zhang Q. Spatial characterization of dissolved trace elements and heavy metals in the upper Han River (China) using multivariate statistical techniques. Journal of Hazardous Materials, 2010, 176(1):579-588

[5] Bidai J, Adiana G, Shazili N A M. Particle size effect of the elements in the South China Sea sediment off Pahang Coastal during the Northeast monsoon (pre-) and the Southwest monsoon (post-) periods. Environmental Earth Sciences, 2016, 75(7):1-12 
[6] Stihi C, Radulescu C, Busuioc G, Popescu I V, Gheboianu A, Ene A. Studies on accumulation of heavy metals from substrate to edible wild mushrooms. Romanian Journal of Physics, 2011, 56(1-2):257-264

[7] Khan K, Lu Y, Khan H, Zakir S, Khan S, Khan A A, Wei L, Wang T. Health risks associated with heavy metals in the drinking water of Swat, northern Pakistan. Journal of Environmental Sciences, 2013, 25(10):2003-2013

[8] Shah M T, Ara J, Muhammad S, Khan S, Tariq S. Health risk assessment via surface water and sub-surface water consumption in the mafic and ultramafic terrain, Mohmand agency, northern Pakistan. Journal of Geochemical Exploration, 2012, 118:60-67

[9] Adiana G, Shazili N A M, Marinah M A. Cadmium, manganese and lead distribution in the South China Sea off the South Terengganu Coast, Malaysia during post-monsoon and pre-monsoon. Journal of Sustainability Science and Management, 2011, 6(2):181-192

[10] Voica C, Kovacs M, Dehelean A, Ristoiu D, Iordache A. ICP-MS determinations of heavy metals in surface waters from Transylvania. Romanian Journal of Physics, 2012, 57(6-7):1184-1193

[11] Idris A M. Combining multivariate analysis and geochemical approaches for assessing heavy metal level in sediments from Sudanese harbors along the Red Sea coast. Microchemical Journal, 2008, 90(2):159-163

[12] Ayni F E, Cherif S, Jrad A, Trabelsi-Ayadi M. Impact of treated wastewater reuse on agriculture and aquifer recharge in a coastal area: Korba case study. Water Resources Management, 2011, 25(9):2251-2265

[13] Atibu E K, Devarajan N, Thevenon F, Mwanamoki P M, Tshibanda J B, Mpiana P T, Prabakar K, Mubedi J I, Wildi W, Poté J. Concentration of metals in surface water and sediment of Luilu and Musonoie Rivers, Kolwezi-Katanga, Democratic Republic of Congo. Applied Geochemistry, 2013, 39:26-32

[14] Venugopal T, Giridharan L, Jayaprakash M, Velmurugan P M. A comprehensive geochemical evaluation of the water quality of River Adyar, India. Bulletin of Environmental Contamination and Toxicology, 2009, 82(2):211-217

[15] Khadse G K, Patni P M, Kelkar P S, Devotta S. Qualitative evaluation of Kanhan River and its tributaries flowing over central Indian plateau. Environmental Monitoring and Assessment, 2008, 147(1):83-92

[16] Juang D F, Lee C H, Hsueh S C. Chlorinated volatile organic compounds found near the water surface of heavily polluted rivers. International Journal of Environmental Science and 
Technology, 2009, 6(4):545-556

[17] Sekabira K, Oryem-Origa H, Basamba T A, Mutumba G, Kakudidi E. Assessment of heavy metal pollution in the urban stream sediments and its tributaries. International Journal of Environmental Science and Technology, 2010, 7(3):435-446

[18] Giri S, Singh A K. Risk assessment, statistical source identification and seasonal fluctuation of dissolved metals in the Subarnarekha River, India. Journal of Hazardous Materials, 2014, 265:305-314

[19] Srebotnjak T, Carr G, de Sherbinin A, Rickwood C. A global water quality index and hot-deck imputation of missing data. Ecological Indicators, 2012, 17:108-119

[20] Su S, Xiao R, Mi X, Xu X, Zhang Z, Wu J. Spatial determinants of hazardous chemicals in surface water of Qiantang River, China. Ecological Indicators, 2013, 24:375-381

[21] Islam M S, Han S, Masunaga S. Assessment of trace metal contamination in water and sediment of some rivers in Bangladesh. Journal of Water and Environment Technology, 2014, 12(2):109-121

[22] Copat C, Bella F, Castaing M, Fallico R, Sciacca S, Ferrante M. Heavy metals concentrations in fish from sicily (Mediterranean sea) and evaluation of possible health risks to consumers. Bulletin of Environmental Contamination and Toxicology, 2012, 88(1):78-83

[23] Ahmad A, Othman M S. Heavy metal concentrations in sediment and fishes from Lake Chini, Pahang, Malaysia. Journal of Biological Sciences, 2010, 10(2):93-100

[24] Mathews T, Fisher N S. Dominance of dietary intake of metals in marine elasmobranch and teleost fish. Science of the Total Environment, 2009, 407(18):5156-5161

[25] Avigliano E, Schenone N F, Volpedo A V, Goessler W, Fernández Cirelli A. Heavy metals and trace elements in muscle of silverside (Odontesthes bonariensis) and water from different environments (Argentina): Aquatic pollution and consumption effect approach. Science of the Total Environment, 2015, 506-507:102-108

[26] World Health Organization (WHO). Guidelines for drinking water quality. Geneva: WHO, 2004

[27] Department of Environment (DOE). Malaysia environmental quality report 2006. Putrajaya: Ministry of Natural Resources and Environment Malaysia, 2007

[28] Krishna P, Jyothirmayi V, Madhusudhana Rao K. Human health risk assessment of heavy metal accumulation through fish consumption, from Machilipatnam Coast, Andhra Pradesh, India. International Research Journal of Public and Environmental Health, 2014, 1(5):121-125 [29] Sary A A, Mohammadi M. Human health risk assessment of heavy metals in fish from 
freshwater. Research Journal of Fisheries and Hydrobiology, 2011, 6(4):404-411

[30] Ikem A, Egilla J. Trace element content of fish feed and bluegill sunfish (Lepomis macrochirus) from aquaculture and wild source in Missouri. Food Chemistry, 2008, 110(2):301-309

[31] Vettori MV, Alinovi R, Belletti S, Goldoni M, Franchini I, Multi A. In vitro model for the evaluation of the neurotoxicity of methyl Mercury: Current state of knowledge. La Medicina del Lavoro, 2003, 94(2):183-191

[32] Akoto O, Bismark E F, Darko G, Adei E. Concentrations and health risk assessments of heavy metals in fish from the Fosu Lagoon. International Journal of Environmental Research, 2014, 8(2):403-410

[33] Kramer K J M. Inorganic contaminants in the water column: Sampling and sampling strategy. International Journal of Environmental Analytical Chemistry, 1994, 57(3):179-188

[34] Eaton A D, Clesceri L S, Greenberg A E. Standard methods for the examination of water and wastewater. Washington DC: American Public Health Association, 1995

[35] Standard Methods. 1060 collection and preservation of samples. American Public Health Association, American Water Works Association and Water Environment Federation: Washington DC, 2011

[36] Azaman F, Juahir H, Yunus K, Azid, Kamarudin M K A, Toriman M E, Mustafa A D, Amran M A, Che H C N, Mohd S A S. Heavy metal in fish: Analysis and human health-A review. Jurnal Teknologi, 2015, 77(1):61-69

[37] Osman R, Saim N, Juahir H, Abdullah M P. Chemometric application in identifying sources of organic contamonations in Langat river basin. Environmental Monitoring and Assessment, 2012, 184(2):1001-1014

[38] Juahir H, Zain S M, Yusoff M K, Hanidza T I T, Armi A S M, Toriman M E, Mokhtar M. The spatial water quality assessment of Langat River Basin (Malaysia) using environmetric techniques. Environmental Monitoring and Assessment, 2011, 173(1-4):625-641

[38] Wu M L, Wang Y S, Sun C C, Wang H, Dong J D, Yin J P, Han S H. Identification of coastal water-quality by statistical analysis methods in Daya Bay, South China Sea. Marine Pollution Bulletin, 2010, 60(6):852-860

[40] Gyawali S, Techato K, Yuangyai C, Monprapusson S. Evaluation of surface water-quality using multivariate statistical technique: A case study of U-Tapao river basin, Thailand. KMITL Science and Technology Journal, 2012, 12(1):7-20

[41] United States Environmental Protection Agency (US-EPA). Guidance for performing 
aggregate exposure and risk assessments. Washington DC: US-EPA, 1999

[42] United States Environmental Protection Agency (US-EPA). Handbook for non-cancer health effects evaluation. Washington DC: US-EPA, 2000

[43] Khan S, Cao Q, Zheng Y M, Huang Y Z, Zhu Y G. Health risks of heavy metals in contaminated soils and food crops irrigated with wastewater in Beijing China. Environmental Pollution, 2008, 152(3):686-692

[44] Muhammad S, Shah M T, Khan S. Arsenic health risk assessment in drinking water and source apportionment using multivariate statistical techniques in Kohistan region, northern Pakistan. Food and Chemical Toxicology, 2010, 48(10):2855-2864

[45] Muhammad S, Shah M T, Khan S. Health risk assessment of heavy metals and their source apportionment in drinking water of Kohistan region, northern Pakistan. Microchemical Journal, 2011, 98(2):334-343

[46] United States Environmental Protection Agency (US-EPA). Guidelines for exposure assessment. Washington DC: US-EPA, 1992

[47] Food and Agriculture Organization of the United Nations (FAO). Overall study of the Messara Plain: Report on study of the water resources and their exploitation for irrigation in eastern Crete. FAO Report No. AGL:SF/GRE/31, Rome: FAO, 1972

[48] Farrell-Poe K. Water quality and monitoring. 2005, https://cals.arizona.edu/ watershedsteward/resources/docs/guide/(10)Water $\%$ 20Quality.pdf

[49] World Health Organization (WHO). Exposure to arsenic: A major public health concern. Geneva: WHO, 2010

[50] Agency for Toxic Substance and Disease Registry (ATSDR). Toxicological profile for cadmium. Georgia: US Department of Health and Human Services, 2012

[51] Lu L T, Chang I C, Hsiao T Y, Yu Y H, Ma H W. Identification of pollution source of cadmium in soil: application of material flow analysis and a case study in Taiwan. Environmental Science and Pollution Research International, 2007, 14(1):49-59

[52] Boehme S, Panero M. Pollution prevention and management strategies for cadmium in the New York/New Jersey Harbor. New York: Academy of Sciences, 2003

[53] Agency for Toxic Substance and Disease Registry (ATSDR). Toxicological profile for arsenic. Georgia: US Department of Health and Human Services, 2000

[54] Alimonti A, Petrucci F, Krachler M, Bocca B, Caroli S. Reference values for chromium, nickel and vanadium in urine of youngsters from the urban area of Rome. Journal of Environmental Monitoring, 2000, 2(4):351-354 
[55] Johnson J, Schewel L, Graedel T E. The contemporary anthropogenic chromium cycle. Environmental Science and Technology, 2006, 40(22):7060-7069

[56] Avudainayagam M, Megharaj G, Owens R S, Kookana D, Chittleborough R, Naidu. Chemistry of chromium in soils with emphasis on tannery waste sites. In G. W. Ware (Ed.), Reviews of environmental contamination and toxicology. New York: Springer, 2003, pp. 53-91

[57] Lin Y, Chang-Chien G, Chiang P, Chen W, Lin Y. Multivariate analysis of heavy metal contaminations in seawater and sediments from a heavily industrialized harbor in Southern Taiwan. Marine Pollution Bulletin, 2013, 76(1):266-275

[58] Zulkifli S Z, Mohamat-Yusuff F, Arai T, Ismail A, Miyazaki N. An assessment of selected trace elements in intertidal surface sediments collected from the Peninsular Malaysia. Environmental Monitoring and Assessment, 2010, 169(1-4):457-472

[59] Ismail Z, Salim K, Othman S Z, Ramli A H, Shirazi S M, Karim R, Khoo S Y. Determining and comparing the levels of heavy metal concentrations in two selected urban river water. Measurement, 2013, 46(10):4135-4144

[60] Bhardwaj V, Singh D S, Singh A K. Environmental repercussions of cane sugar industries on the Chhoti Gandak river basin, Ganga Plain, India. Environmental Monitoring and Assessment, 2010, 171(1):321-344

[61] Corbi J J, Trivinho S S, Dos S A. Environmental evaluation of metals in sediments and dragonflies due to sugar cane cultivation in neotropical streams. Water, Air, and Soil Pollution, 2008, 195(1-4):325-333

[62] Tiwari M K, Bajpai S, Dewangan U K, Tamrakar R K. Assessment of heavy metal concentrations in surface water sources in an industrial region of central India. Karbala International Journal of Modern Science, 2015, 1(1):9-14

[63] Agency for Toxic Substance and Disease Registry (ATSDR). Public health statement: Cobalt. Georgia: US Department of Health and Human Services, 2004

[64] Cempel M, Nikel G. Nickel: A review of its sources and environmental toxicology. Polish Journal of Environmental Studies, 2006, 15(3):375-382

[65] European Union (EU). Nickel sulphate risk assessment. Copenhagen: Environmental Environment Agency, 2004

[66] World Health Organization (WHO). Exposure to cadmium: A major public health concern. Geneva: WHO, 2010

[67] Ayirala S C, Vijapurapu C S, Rao D N. Beneficial effects of wettability altering 
surfactants in oil-wet fractured reservoirs. Journal of Petroleum Science and Engineering, 2006, 52(1):261-274

[68] Carr G. M., Neary J. P. Water quality for ecosystem and human health. Ontario: UNEP/Earthprint; 2008

[69] TDC Environmental. Copper sources in urban runoff and shoreline activities. California: Clean Estuary Partnership, 2004

[70] Center for Sustainable Systems (CSS). Municipal solid waste. Ann Arbor: University of Michigan, 2015

[71] World Health Organization (WHO). Arsenic and arsenic compounds. Geneva: WHO, 2001

[72] Devesa V, Velez D, Montoro R. Effect of thermal treatments on arsenic species contents in food. Food and Chemical Toxicology, 2008, 46(1):1-8

\section{How to cite this article:}

Azaman F., Juahir H., Yunus K., Azid A., Khalit S. I., Mustafa A. D., Amran M. A., Hasnam C. N. C., Abidin M. Z. A. Z. and Yusri M. A. M. Metal concentration at surface water using multivariate analysis and human health risk assessment. J. Fundam. Appl. Sci., 2017, 9(2S), 217-237. 